\title{
Effects of Environmental Exposure to Lead and Cadmium on Male Fertility
}

\author{
Ahmed Zaki ${ }^{1}$, Fouad H. A. ${ }^{2}$, Mostafa A. M. ${ }^{1}$, Tarek M. E. ${ }^{3}$, Ahmed W. A. ${ }^{4}$
}

\begin{tabular}{ll}
\hline & ABSTRACT \\
\cline { 2 - 3 } KEYWORDS & $\begin{array}{c}\text { Chronic exposure to heavy metals represents a medical challenge especially in } \\
\text { Lead, } \\
\text { Cadmium, } \\
\text { FSH, }\end{array}$ \\
LH. & $\begin{array}{l}\text { consent, the present study included 70 infertile couples (without female infertility factor) } \\
\text { attending the infertility clinics (Dermatology and Venereology Department; Al-Azhar }\end{array}$ \\
& $\begin{array}{l}\text { Faculty of Medicine; New Damietta); who were well-known to be exposed to lead and/or } \\
\text { cadmium confirmed by measuring blood lead and cadmium levels, and another 30 healthy } \\
\text { fertile males without evidence of environmental exposure were included as controls. All } \\
\text { patients underwent history taking, clinical and andrological examination and laboratory } \\
\text { investigations (complete blood count, blood glucose level, renal and liver function tests and } \\
\text { hormonal profile (serum FSH, LH, estrogen and testosterone) with measurement of lead } \\
\text { and cadmium levels using graphite furnace atomic absorption spectrophotometry. Finally, } \\
\text { a sample of semen was obtained for semen analysis. It was concluded that there was high } \\
\text { concentrations of lead and cadmium linked to male infertility as revealed by changes in } \\
\text { hormonal profile and seminal parameters. }\end{array}$
\end{tabular}

\section{Introduction}

Worldwide, about 1 in 7 couples have problems in conceiving. About $80 \%$ or higher of couples with regular intercourse with no use of any methods of contraception would attain a pregnancy by one year and about $92 \%$ could get a pregnancy by 2 years (Sandhu and Tu, 2017).

Infertility affects males and females equally; although many people believe that infertility is a female problem. In industrial

\footnotetext{
${ }^{(1)}$ Forensic Medicine and Clinical Toxicology Department, Al-Azhar University (New Damietta).

${ }^{(2)}$ Forensic Medicine and Clinical Toxicology Department, Al-Azhar University (Cairo).

${ }^{(3)}$ Clinical Pathology Department, Al-Azhar University (New Damietta).

(4) Dermatology and Venereology Department, Al-Azhar University (New Damietta).
}

countries, $15 \%$ of couples at their reproductive years have difficulty conceiving naturally (Jurewicz et al. 2013).

A male factor was included in about half of such couples and the cause still unidentified in $25 \%$ of male factor infertility cases. As medical history cannot be elucidated in all male factor infertility subjects, these observations may be associated with an effect of occupational and environmental factors (De Fleurian et al., 2009).

Although many factors, e.g., diseases, lifestyle, stress and obesity, are accountable for decreasing semen excellence, environmental toxins are also suggested to play a pivotal role in worsening male reproduction health. Environmental toxicants as lead $(\mathrm{Pb})$, cadmium (Cd) or phthalate esters (di (2-ethylhexyl) phthalate (DEHP), dibutyl phthalate (DBP) and diethyl phthalate (DEP)) extensively found in 
diverse environmental strata are associated with reduction of sperm count and motility (Sengupta, 2013). Human exposure to metals usually happens by oral intake of contaminated foodstuffs, drinking polluted water, exposure to cigarette smoke and via eating food packed and preserved in recycled plastic materials. Highly acidic food has a greater detrimental effect on human health because plasticizers leak more easily to such foods (Bernard, 2008). Studies evaluating the toxic link with semen quality and sex steroid hormones in humans provide conflicting results, these findings either have no association (Mendiola et al., 2011) or have significant association (ShuGuang et al., 2011).

These chemical substances exert its function by an endocrine-disrupting action with disruption of hormone regulations, through the hypothalamic-pituitary-testicular axis or direct inhibition of androgen formation in Leydig cells (Jurewicz et al. 2013). The aim of the present study was to estimate the level of (lead and cadmium) in infertile males.

\section{Patients and methods}

This study was designed as an analytical observational case-controlled study. The study was conducted on (100) subject divided into two groups.

Group (1): Case group: Seventy patients were males in infertile couples (without female infertility factor) attending the infertility clinics (Dermatology and Venereology Department; Al-Azhar Faculty of Medicine; New Damietta); who were well-known to be exposed to lead and/or cadmium confirmed by measuring blood lead and cadmium levels.

Group (2): Control group: thirty fertile males, without evidence of environmental exposure were included as a control group. Levels of lead and cadmium were measured to confirm absence of exposure.
Inclusion criteria were as the following: 1) Male patients aged 18 to 45 years; and 2) Absence of current medication known to impair semen parameters.

On the other hand, exclusion criteria included: 1) Patients with history of varicocoele, cryptorchidism or endocrine hypogonadism (abnormal hormonal concentrations), 2) Patients with chemo- and/or radiotherapy, and 3) Patients with anomalies in the karyotype or Y chromosome microdeletions, 3) Male patients with chronic diseases such as diabetes mellitus, hypertension, bilharziasis, syphilis and tuberculosis.

The following questionnaire was filled with the patient himself or by the researcher. The items of the questionnaire were divided into 4 parts: Part (1) collected general information of the participant included: age, place of birth and age of marriage. The second part is about risk factors known to impair semen quality, including history of genital pathology. Part (3) asked about lifestyle: current [for a duration of at least 3 months] consumption of tobacco, alcohol, or drugs. Part (4) assessed the subjects' professional exposure using: 1] the social and economic class; 2] current and past occupations and occupational exposure considering the exact professional activity. An occupation exposure was marked as positive if there was current exposure [ $>1$ $\mathrm{h} / \mathrm{wk}$ and since 3 months or more] or past exposure [not current; was continued for 1 or more years in the past and $>1 \mathrm{~h} / \mathrm{wk}]$.

Full clinical and andrological examination were done for all participants. A $10 \mathrm{ml}$ of venous blood were obtained for investigation of complete blood count (C.B.C), blood glucose level, renal and liver function tests and hormonal profile (FSH, LH, serum estrogen and testosterone) and measurement of cadmium and lead. 
Finally, a sample of semen was obtained for semen assessment. All participants were instructed to abstain from sexual intercourse for at least 3 successive days before giving the semen sample. The semen samples were collected in sterile plastic containers and permitted to liquefy for $30 \mathrm{~min}$. Thereafter, samples were analyzed by direct microscopy.

\section{Statistical Analysis}

The statistical package for social science (SPSS), version 22 (IBM $^{\circledR}$ SPSS $^{\circledR}$ Inc, USA) was studied to perform statistical analysis. Quantitative data was expressed as mean and standard deviation; while qualitative were expressed as frequency and percent distribution. For comparison between two groups, the independent samples student $(\mathrm{t})$ test and Chi square $\left(\chi^{2}\right)$ test were used for quantitative and qualitative data respectively. $\mathrm{P}$ value $<0.05$ was considered significant.

\section{Results}

The present study includes 70 infertile males, and another 30 healthy controls. Patient age ranged from 24 to 38 years, the mean age was $33.75 \pm 2.84$ years. The age at marriage ranged from 20 to 30 years, the mean age at marriage was $24.01 \pm 1.56$ years; and there was no significant difference between study and control groups regarding age and age at marriage.

Weight of studied populations in the present study ranged from 62 to $85 \mathrm{Kg}$, the mean value was $72.95 \pm 5.57 \mathrm{Kg}$; the height ranged from 162 to $179 \mathrm{~cm}$, the mean value was $170.95 \pm 3.92 \mathrm{~cm}$; BMI ranged from 20.96 to $29.07 \mathrm{Kg} / \mathrm{m}^{2}$, the mean value was $24.93 \pm 1.34 \mathrm{Kg} / \mathrm{m}^{2}$; there was no significant difference between study and control groups regarding weight, height or BMI.

Smoking habit was positive in $41 \%$ of studied populations, and there was statistically significant increase of smokers in study when compared to control group $(52.9 \%$ versus $13.3 \%$ respectively) (Table 1 ). Regarding CBC findings, there was statistically significant decrease of hemoglobin, RBCs and hematocrit in the study when compared to the control group $(9.95 \pm 0.60,3.19 \pm 0.32$ and $31.44 \pm$ 2.87 versus $12.48 \pm 0.54,4.16 \pm 0.34$ and 40.89 \pm 3.53 successively).

On the other side, there was no significant difference between study and control groups as regard to white blood cells and platelet count. In the present study, serum creatinine ranged from 0.30 to 2.30 , the mean value was $1.02 \pm 0.40 \mathrm{mg} / \mathrm{dl}$; blood urea ranged from 10 to 47 , the mean value was $29.28 \pm 10.56$ $\mathrm{mg} / \mathrm{dl}$ and there was significant increase of serum creatinine and blood urea in the study group when compared to control group (1.20 \pm $0.32,35.85 \pm 3.51$ versus $0.60 \pm 0.21$ and 13.93 \pm 1.77 respectively).

There was no significant difference between study and control groups as regard to serum albumin, ALT or AST. Results of the present study revealed that, there was no significant difference between study and control groups as regard to fasting and postprandial blood sugar. 
Table (1): Distribution of the studied populations as regard to personal chercteristics.

\begin{tabular}{|l|c|c|c|c|}
\hline \multicolumn{1}{|c|}{ Variables } & $\begin{array}{c}\text { Study group } \\
\mathbf{n : 7 0} \\
\text { mean } \pm \text { SD }\end{array}$ & $\begin{array}{c}\text { Control group } \\
\mathbf{n : 3 0} \\
\text { mean } \pm \text { SD }\end{array}$ & test & p value \\
\hline Age $($ year) mean \pm SD & $34.04 \pm 2.72$ & $33.06 \pm 3.06$ & 1.58 & 0.11 \\
\hline Age at marriage $($ year) mean \pm SD & $23.90 \pm 1.48$ & $24.26 \pm 1.74$ & 1.07 & 0.28 \\
\hline Weight $(\mathrm{Kg})$ mean \pm SD & $73.10 \pm 5.15$ & $72.60 \pm 6.52$ & 0.40 & 0.68 \\
\hline Height $(\mathrm{cm})$ mean \pm SD & $170.67 \pm 3.19$ & $171.60 \pm 5.26$ & 1.08 & 0.28 \\
\hline BMI $\left(\mathrm{Kg} / \mathrm{m}^{2}\right)$ mean \pm SD & $25.07 \pm 1.36$ & $24.61 \pm 1.26$ & 1.60 & 0.11 \\
\hline Smoking $\mathrm{n}(\%)$ & $37(52.9 \%)$ & $4(13.3 \%)$ & 13.56 & $<0.001^{*}$ \\
\hline
\end{tabular}

BMI: body mass index, SD: standard deviation, Kg: kilogram, cm: centimeter, n: number, * significant.

There was statistically significant increase of FSH and LH in study when compared to control group $(6.08 \pm 0.42 \mathrm{IU} / \mathrm{L}$, $8.04 \pm 0.90 \mathrm{IU} / \mathrm{L}$ versus $4.48 \pm 0.38 \mathrm{IU} / \mathrm{L}$ and $6.83 \pm 0.77$ respectively). On the other hand, there was statistically significant decrease of estradiol and testosterone in study when compared to control group $(51.87 \pm 6.70 \mathrm{pg} / \mathrm{ml}$, $351.02 \pm 34.47 \mathrm{ng} / \mathrm{ml}$ versus $82.23 \pm 4.99 \mathrm{pg} / \mathrm{ml}$ and $380.02 \pm 57.53 \mathrm{ng} / \mathrm{ml}$ respectively) (Table 2).

Semen analysis revealed that there was statistically significant decrease of ejaculate volume, sperm count, sperm concentrations, live sperms, rapid and progressive motility in study when compared to control group (Table 3).

Regarding levels of lead, it ranged from 12 to $30.1 \mu \mathrm{g} / \mathrm{dl}$ and there was statistically significant increase in study when compared to control group $(37.26 \pm 7.64$ versus $17.32 \pm 3.45$ $\mu \mathrm{g} / \mathrm{dl}$ respectively). In addition, cadmium levels ranged from 1 to $9 \mu \mathrm{g} / \mathrm{dl}$, and there was statistically significant increase in study when compared to control group $(5.36 \pm 1.45$ vs $1.87 \pm 0.83 \mu \mathrm{g} / \mathrm{dl}$ respectively) (Table 4 ).

Table (2): Laboratory investigations in the studied populations.

\begin{tabular}{|l|c|c|c|c|}
\hline \multicolumn{1}{|c|}{ Variables } & $\begin{array}{c}\text { Study group } \\
\mathbf{n}: 70 \\
\text { mean } \pm \text { SD }\end{array}$ & $\begin{array}{c}\text { Control group } \\
\text { n:30 } \\
\text { mean } \pm \text { SD }\end{array}$ & test & p value \\
\hline Creatinine (mg/dl) & $1.20 \pm 0.32$ & $0.60 \pm 0.21$ & 9.08 & $<0.001^{*}$ \\
\hline Blood urea (mg/dl) & $35.85 \pm 3.51$ & $13.93 \pm 1.77$ & 32.23 & $<0.001^{*}$ \\
\hline Albumin (g/dl) & $4.23 \pm 0.33$ & $4.36 \pm 0.27$ & 1.80 & 0.07 \\
\hline ALT (IU/dl) & $24.28 \pm 1.88$ & $24.00 \pm 1.89$ & 0.69 & 0.49 \\
\hline AST(IU/dl) & $35.05 \pm 9.48$ & $35.13 \pm 8.48$ & 0.04 & 0.97 \\
\hline Fasting blood sugar $(\mathrm{mg} / \mathrm{dl})$ & $107.52 \pm 4.58$ & $106.13 \pm 5.38$ & 1.32 & 0.18 \\
\hline Postprandial blood sugar $(\mathrm{mg} / \mathrm{dl})$ & $167.28 \pm 10.83$ & $169.86 \pm 13.94$ & 0.99 & 0.32 \\
\hline FSH (IU/L) & $6.08 \pm 0.42$ & $4.48 \pm 0.38$ & 17.74 & $<0.001^{*}$ \\
\hline LH (IU/L) & $8.04 \pm 0.90$ & $6.83 \pm 0.77$ & 6.34 & $<0.001^{*}$ \\
\hline Estradiol $(\mathrm{pg} / \mathrm{ml})$ & $51.87 \pm 6.70$ & $82.23 \pm 4.99$ & 22.26 & $<0.001^{*}$ \\
\hline Testosterone $(\mathrm{ng} / \mathrm{ml})$ & $351.02 \pm 34.47$ & $447.66 \pm 41.35$ & 12.08 & $<0.001^{*}$ \\
\hline
\end{tabular}

ALT: Alanine transaminase, AST: Aspartate transaminase, FSH: Follicle-stimulating hormone, LH: Luteinizing hormone, n: number, * significant, SD: standard deviation. 
Table (3): Semen analysis of studied populations.

\begin{tabular}{|l|c|c|c|c|c|c|}
\hline \multirow{2}{*}{ Variables } & \multicolumn{2}{|c|}{$\begin{array}{c}\text { Study group } \\
\text { n:70 }\end{array}$} & \multicolumn{2}{c|}{$\begin{array}{c}\text { Control group } \\
\text { n:30 }\end{array}$} & \multirow{2}{*}{ t } & \multirow{2}{*}{ p } \\
\cline { 2 - 6 } & Mean & SD & Mean & SD & & \\
\hline Ejaculate volume $(\mathrm{ml})$ & 3.74 & 0.66 & 4.43 & 0.67 & 4.71 & $<0.001^{*}$ \\
\hline Semen pH & 8.13 & 0.04 & 8.13 & 0.05 & 0.40 & 0.68 \\
\hline Sperm count x10 & 201.90 & 12.82 & 268.40 & 24.03 & 17.99 & $<0.001^{*}$ \\
\hline Sperm concentration\% & 55.31 & 8.84 & 61.72 & 9.79 & 3.21 & 0.002 \\
\hline Abnormal forms\% & 46.65 & 2.35 & 46.56 & 2.327 & 0.17 & 0.86 \\
\hline Live sperms\% & 55.45 & 2.371 & 66.13 & 3.37 & 18.06 & $<0.001^{*}$ \\
\hline Rapid motility & 49.12 & 1.91 & 51.10 & 2.33 & 4.41 & $<0.001^{*}$ \\
\hline Progressive motility & 38.04 & 2.03 & 42.60 & 4.108 & 7.42 & $<0.001^{*}$ \\
\hline
\end{tabular}

SD: Standard deviation, n: number, * significant.

Table (4): Lead and cadmium levels of studied populations.

\begin{tabular}{|c|l|c|c|c|c|c|c|}
\hline \multicolumn{2}{|c|}{} & Mean & SD & Minimum & Maximum & t & p \\
\hline \multirow{2}{*}{ Lead $(\mu \mathrm{g} / \mathrm{dL})$} & Study & 37.26 & 7.64 & 22.00 & 55.00 & \multirow{2}{*}{13.67} & \multirow{2}{*}{$<0.001^{*}$} \\
\cline { 2 - 9 } & Control & 17.32 & 3.45 & 12.00 & 30.10 & & \\
\hline \multirow{2}{*}{ Cadium $(\mu \mathrm{g} / \mathrm{L})$} & Study & 5.36 & 1.45 & 2.00 & 9.00 & \multirow{2}{*}{12.24} & $<0.001^{*}$ \\
\cline { 2 - 9 } & Control & 1.87 & 0.83 & 1.00 & 4.20 & & \\
\hline
\end{tabular}

SD: Standard deviation, * significant.

In the present work, each of cadmium and lead were inversely correlated with ejaculate volume, sperm count, sperm concentration, live sperms, rapid mobility, estradiol and testosterone, while both metals were proportionally correlated with FSH and LH (Table 5). 
Table (5): Correlation of lead and cadmium with semen analysis and reproductive hormonal profile.

\begin{tabular}{|l|c|c|}
\hline & Cadmium $(\mu \mathrm{g} / \mathbf{L})$ & Lead $(\boldsymbol{\mu g} / \mathbf{d L})$ \\
\hline Ejaculate volume & $-0.293^{*}$ & $-0.270^{*}$ \\
\hline Sperm count & $-0.703^{*}$ & $-0.708^{*}$ \\
\hline Sperm concentration & $-0.301^{*}$ & $-0.322^{*}$ \\
\hline Live sperms & $-0.648^{*}$ & $-0.758^{*}$ \\
\hline Rapid motility & $-0.373^{*}$ & $-0.339^{*}$ \\
\hline Progressive motility & $-0.408^{*}$ & $-0.538^{*}$ \\
\hline Follicle-stimulating hormone & $0.621^{*}$ & $0.707^{*}$ \\
\hline Luteinizing hormone & $0.405^{*}$ & $0.534^{*}$ \\
\hline Estradiol & $-0.750^{*}$ & $-0.772^{*}$ \\
\hline Testosterone & $-0.579^{*}$ & $-0.599^{*}$ \\
\hline
\end{tabular}

* significant at p 0.01 .

\section{Discussion}

Male infertility can result from anatomical or genetic abnormalities, systemic or neurological diseases, infections, trauma, iatrogenic injury, gonadotoxins and development of sperm antibodies. When a husband and his wife fail to attain pregnancy beyond 1 year of regular sexual activity, an evaluation of both partners is crucial. For male, this assessment includes history, clinical examination, endocrine evaluation and analysis of semen. Several lifestyle factors and environmental issues can have a negative effect on male reproductive health, and the general physician has an essential role in patients' education about modifiable risk factors (National Institute for Health and Care Excellence, 2013).

A male factor is proposed to be responsible for about $50 \%$ of infertile cases, with single main responsibility in $30 \%$ of cases and a co-factor to a female factor in $20 \%$ of cases (Winters and Walsh, 2014).

In the present study, there was no significant difference between study and control groups as regard to age and age at marriage. This age reflected the relatively higher age of patients that coincides with some reduction in testosterone. It was reported that, levels of testosterone decreased with advancement of age in most males, even in males who are healthy and this decrease may start around the age of thirty. The reduction of about $1 \%$ per year of testosterone after the age of 30 years has been called the andropause (Pasqualotto et al., 2004). However, age-specific reduction in testosterone itself cannot explain infertility in the present study, as it was technically accurate described for the decline in testosterone might be "symptomatic hypogonadism in aging males." Hypogonadism is not characterized by any definite level of serum androgens because the testosterone levels that lead to dysfunction varies broadly among individuals (Bhasin et al., 2006).

In addition, the non-significant difference between cases and controls, contradicts the effect of age-associated reduction in testosterone as a causative factor for infertility. There was no significant difference between study and 
controls regarding weight, height or BMI. These results are comparable to previous study which reported that, infertility is more prevalent among men with elevated BMIs. Excess weight is not only linked to high risk of chronic disease, but also increases the risk of reproductive problems. Obesity has negative impact on male fertility (Loret, 2009). Jensen et al. (2004) evaluated over 1558 young males who have paramilitary physical and reported that overweight and obese men had decreased sperm concentration when compared to normal weight age matched controls. Also, the action of obesity on sperm characters has been investigated in different trials that linked increased incidence of azoospermia and oligozoospermia to overweight and obesity (Sermondade et al., 2013).

In the present study, regarding smoking habit, it was positive in $41 \%$ of studied populations, and there was statistically significant increase of smokers in study when compared to control group. Tobacco smoke is harmful to different reproductive functions. Benzo[a]pyrene $(\mathrm{B}[\mathrm{a}] \mathrm{P})$ is reported to be a potent carcinogen, which is one of main constituents in cigarette smoke. Its reactive metabolite adducts with DNA, which can result in mutations. This can result in both male and female infertility. In addition, male smokers had reduced sperm counts, impaired motility of sperms, more abnormal forms and decreased testosterone values; they can possibly contribute to congenital abnormalities and asthma in their sons (Zenzes et al., 1999). Furthermore, the exposure of sperms from non-smokers to the seminal plasma of smokers leads to a marked decrease in sperm motility, acrosome reaction and increased MDA (Arabi and Moshtaghi, 2005).
Evidence of different studies proposes that cigarette smoking may have a harmful action on male fertility by reduction of sperm creation, motility and increasing abnormal forms. Smokers are $60 \%$ more prone to be infertile than non-smokers. Smokers also have high levels of serum estradiol and low levels of LH, FSH and prolactin than non-smokers, all these findings can negatively affect spermatogenesis (Olayemi, 2010).

There was significant increase of serum creatinine and blood urea in the study group when compared to control group. These results are comparable to previous literature, where a convincing relation between abnormal renal function and blood lead levels (BLLs) $<10$ $\mu \mathrm{g} / \mathrm{dL}$ was reported (Fadrowski et al., 2010; Spector et al., 2011). Most of the studies revealed significant changes in kidney functions notably low glomerular filtration rate (GFR) around BLLs $2 \mu \mathrm{g} / \mathrm{dL}$ to $3 \mu \mathrm{g} / \mathrm{dL}$ (Fadrowski et al., 2010; Spector et al., 2011; Basgen and Sobin, 2014).

Some studies reveal association between exposure to lead and renal function; others found no significant difference in renal function in lead workers compared with control subjects (Weaver et al., 2003; Schrader and Marlow, 2014). The contradicting data reported by clinical trials may reflect differences in the methodology of obtaining eGFR (Chung et al., 2014). However, experimental and animal studies show clear evidence of renal injury after low-dose lead exposure. Chronic lead exposure primarily leads to proximal tubular insult with mitochondrial functional damage (Wang et al., 2010).

Semen analysis remains the single most important and useful investigation with a sensitivity of $89.6 \%$, that it is capable to identify 9 out of 10 males with a genuine problem of male infertility (Butt and Akram, 2013). 
Infertility in males is diagnosed when sperm characters are below the WHO normal values (Plachot et al., 2002). The most important of these are decreased sperm concentration (oligospermia), poor sperm motility (asthenospermia) and abnormal morphology (teratospermia). Less important factors include the volume of semen and other markers of epididymal, prostatic and seminal vesicle function (Harris et al., 2011).

The most important and critical cause of infertility is decreased sperm concentration, $90 \%$ of male infertility problems are due to decreased count and there is a proportional correlation between the abnormal semen data and sperm count (Sabra and Al-Harbi, 2014).

The problems with count, motility and abnormal forms of semen arise from disarray in control mechanism, including pretesticular, testicular and post-testicular factors (Wamoto et al., 2007). Hjollund et al. (2000) documented that, $\mathrm{Pb}, \mathrm{Cd}$, and $\mathrm{Hg}$, could negatively affect the male reproduction, by disruption of hypothalamic - pituitary gonadal axis or by direct negative effect on spermatogenesis, leading to impairment of semen quality. A tendency towards reduction of quality has been reported in males exposed to heavy metals. There is significant agreement that high or even moderate values of lead led to fertility problems in males. Fatima et al. (2010) showed that $>40 \mu \mathrm{g} / \mathrm{dL}$ of lead in blood leads to a reduction in sperm count. In addition, they reported lower motility $(<50 \%)$ with levels $>35 \mu \mathrm{g} / \mathrm{dL}$ in whole blood.

Telisman et al. (2007) also showed that high lead concentration in blood $(36.7 \mu \mathrm{g} / \mathrm{dL})$ significantly lowers sperm density and motility. High levels of lead seem to be evidently linked to sperm damage.
Available data also indicate that, lead could exert a harmful effect on semen quality, even at blood lead concentrations $<15 \mu \mathrm{g} / \mathrm{dL}$. In a study included 123 males who had never been exposed to metals, the median blood lead concentrations was $57 \mu \mathrm{g} / \mathrm{dL}$ (range: $2.5-14.9$ ). After adjusting for confounding variables (e.g. age, smoking, alcohol, blood cadmium, serum copper, zinc and selenium), an increase in blood lead was markedly associated with reducing percentages of morphologically healthy and subnormal sperm and with increasing percentages of slow sperm and overly wide sperm (Jurasovic et al., 2004).

In another study, the seminal plasma lead values of males not exposed to lead in their occupation or environment were found to negatively correlate with fertilization ability of sperm acrosome reaction and the fertilization rate when using the IVF procedure, and also with seminal plasma zinc levels (Benoff et al., 2003).

Taken together, the previous trials propose that lead may significantly reduce quality of semen, even at low-levels that is common for general people allover the world. Several trials including lead labors have proved that paternal blood levels of lead of about $30-40 \mu \mathrm{g} / \mathrm{dL}$ are a most likely threshold for high rate of spontaneous abortions, decreased rate of live births and prolonged time to pregnancy (Shiau et al., 2004), although inconsistent findings or a minor incompatibility were also reported (Snijder et al., 2012).

In addition, results are comparable to previous literature reported that, at high concentrations, cadmium could also affect semen quality. According to Akinloye et al. (2006) men with high cadmium levels in seminal plasma $(65 \mu \mathrm{g} / \mathrm{dL})$ had less sperm count and $36 \%$ of motile sperms. Furthermore, cadmium has been detected in markedly high values in blood of ex-smoker males and involved as one of the etiologies of asthenoteratozoospermia (Omu et al., 1995). 
In a more recent study, the relationship between $\mathrm{Cd}$ levels and spermatograms or the hypothalamic-pituitary-gonadal (HPG) - axis and the correlation of blood and seminal plasma $\mathrm{Cd}$ concentrations with semen characters and hormonal levels were investigated in 60 infertile Nigerian males. The blood and seminal plasma levels of cadmium were higher in azoospermic men in comparison to oligozoospermic and control males while a significant inverse correlation was shown between serum $\mathrm{Cd}$ and all examined semen characters except volume of semen. A proportional correlation between seminal plasma $\mathrm{Cd}$ and $\mathrm{FSH}$ was also observed. The data establish the role of $\mathrm{Cd}$ in male infertility (Akinloye et al., 2006). Furthermore, results of the present study are comparable to results of the study done by Jurasovic et al. (2004) who reported that, an inverse correlation has been reported between blood cadmium, sperm motility, volume of semen, sperm count and concentration. In other studies, marked relationships were found between high serum values of estradiol, FSH and testosterone that have been found with respect to blood cadmium (Jurasovic et al., 2004).

Another study of males not exposed to $\mathrm{Cd}$ also revealed a crucial relationship between high serum testosterone and blood Cd levels (Telisman et al., 2000).

The aftercoming acute effects have been reported in experimental animals injected with soluble salts of $\mathrm{Cd}$ : reduced testosterone; a low testicular weight and size and similar low weight and size of epididymis, vas deferens, prostate and seminal vesicles; reduced sperm production and motility; and suppressed libido and reproductive capacity (Chen et al., 2012).
On the other hand, results of the present work are in contradiction to those reported by Sengupta (2013) who reported that, there were no significant correlations between semen quality and cadmium levels in semen, seminal plasma, or blood. This can be explained by different sample size and ethnicity. A study on the effect of combined exposure to lead and cadmium on the testes of rats showed that animals orally exposed to the combination exhibited significantly more pronounced pathological testicular changes, with a reduction in sperm counts, compared with animals exposed to either of the metals alone (Pandya et al., 2012).

In short, results of the present work revealed that, higher levels of lead and cadmium were significantly associated with male infertility as revealed by changes in hormonal profile and seminal parameters.

\section{Conclusion}

Higher levels of lead and cadmium were associated with male infertility as revealed by changes in hormonal profile and seminal parameters. Environmental exposure to $\mathrm{Pb}$ and $\mathrm{Cd}$ may adversely affects fertility in men.

Smoking habits and anemia are significant factors in male infertility. Kidney functions and reproductive hormonal profile are deleteriously affected in males exposed to $\mathrm{Pb}$ and $\mathrm{Cd}$ in regular manner.

Each of cadmium and lead were inversely correlated with semen parameters as, ejaculate volume, sperm count, sperm concentration, live sperms and rapid mobility. Semen analysis is the single most useful and fundamental investigation of male infertility. 


\section{References}

Akinloye, O.; Arowojolu, A. and Shittu, O. (2006): "Cadmium toxicity: A possible cause of male infertility in Nigeria". Reprod. Bio., 6:17-30.

Arabi, M. and Moshtaghi, H. (2005): "Influence of cigarette smoking on spermatozoa via seminal plasma". Andrologia, 37: 119-124.

Basgen, J. and Sobin, C. (2014): "Early chronic low-level lead exposure produces glomerular hypertrophy in young C57BL/6J mice". Toxicology Letters, 225 (1): 48-56.

Benoff, S.; Centola, G.; Millan, C.; et al. (2003): "Increased seminal plasma lead levels adversely affect the fertility potential of sperm in IVF". Hum. Reprod., 18(2):374-383.

Bernard, A. (2008):"Cadmium \& its adverse effects on human health". Indian J. Med. Res., 128:557-564.

Bhasin, S.; Cunningham, G. and Hayes, F. (2006): "Testosterone therapy in adult men with androgen deficiency syndromes: An endocrine society clinical practice guideline". J. Clin. Endocrinol. Metab., 91:1995-2010.

Butt, F. and Akram, N. (2013): "Semen analysis parameters: Experiences and insight into male infertility at a tertiary care hospital in Punjab". J. Pak. Med. Assoc., 63:558-562.

Chen, W.; Ercal, N. and Huynh, T. (2012):"Characterizing N-acetyl cysteine (NAC) and N-acetylcysteine amide (NACA) binding for lead poisoning treatment". J. Colloid Interface Sci., 371(1):144-149.
Chung, S.; Chung, J. and Kim, S. (2014):"Blood lead and cadmium levels and renal function in Korean adults". Clin. Exp. Nephrol., 18:726-734.

De Fleurian; Perrin, J. and Achard V. (2009): "Occupational exposures obtained by questionnaire in clinical practice and semen quality". J. Androl., 30:566-579.

Fadrowski, J.; Navas-Acien, A. and TellezPlaza, M. (2010): "Blood lead level and kidney function in US adolescents: The Third National Health and Nutrition Examination Survey". Arch Intern. Med., 170:75-82.

Fatima, P.; Debnath, B. and Hossain, M. (2010): "Relationship of blood and semen lead level with semen parameter". Mymensingh Med. J., 19: 405-414.

Harris, I.; Fronczak, C.; Roth, L., et al. (2011): "Fertility and the aging male". Rev. Urol., 13: 184-190.

Hjollund, N.; Bonde, J. and Jensen, T. (2000): "Male-mediated spontaneous abortion among spouses of stainless steel welders". Scand. J. Work Environ. Health, 26: 187-192.

Jurasovic, J.; Cvitković, P.; Pizent, A.; et al. (2004): "Semen quality and reproductive endocrine function with regard to blood cadmium in Croatian male subjects". Biometals, 17:735-743.

Jensen T.K.; Andersson A.M.; Jorgensen N.; et al., (2004):"Body mass index in relation to semen quality and reproductive hormones among 1,558 Danish men". Fertil. Steril., 8: 863-870.

Jurewicz, J.; Radwan, M.; Sobala, W.; et al. (2013):"Human urinary phthalate metabolites level and main semen parameters, sperm chromatin structure, sperm aneuploidy and reproductive hormones". Reprod. Toxicol., 42:232241. 
Loret, D.J.R. (2009):"Obesity and its relationship to infertility in men and women". Obstet. Gynecol. Clin. North Am., 3: 333-346.

Mendiola, J.; Moreno, J. and Roca M, (2011): "Relationships between heavy metal concentrations in three different body fluids and male reproductive parameters: A pilot study". Environ. Health, 10:6-11.

National Institute for Health and Care Excellence (2013): Fertility problems: Assessment and treatment. London: NICE, Available at www.nice.org. uk/guidance/ cg156 [Accessed 12 July 2017].

Olayemi F. O. (2010):"A review on some causes of male infertility". African J. Biotechnol., 20: 2834-2842.

Omu, A.; Dashtu, H. and Mohammed, A. (1995): "Significance of trace elements in semen of infertile men". Nutrition, 11:502-505.

Pandya, C.; Pillai, P.; Nampoothiri, L.; et al. (2012): "Effect of lead and cadmium co-exposure on testicular steroid metabolism and antioxidant system of adult male rats". Andrologia J., 44(1):813-822.

Pasqualotto, F.; Lucon, A. and Hallak, J. (2004): "Risks and benefits of hormone replacement therapy in older men". Rev. Hosp. Clin. Fac. Med. Sao. Paulo., 59: 32-38.

Plachot, M.; Belaisch-Allart, J. and Mayenga, J. (2002):"Outcome of conventional IVF and ICSI on sibling oocytes in mild male factor infertility". Hum. Reprod., 17: 362369.

Sabra' S. and Al-Harbi, M. (2014): "An influential relationship of seminal fluid microbial infections and infertility, Taif Region, KSA". World J. Med. Sci., 10: 32-37.

Sandhu, J. and Tu, H. (2017): "Recent advances in managing chronic prostatitis/ chronic pelvic pain syndrome". F1000Res., (25): 1747.

Schrader, S.M. and Marlow, K. (2014): "Assessing the reproductive health of men with occupational exposures". Asian J. Androl., 16(1):23-30.

Sengupta P. (2013):"Environmental and occupational exposure of metals and their role in male reproductive functions". Drug Chem. Toxicol., 36:353-368.

Sermondade, N.; Faure, C. and Fezeu, L. (2013): "BMI in relation to sperm count: an updated systematic review and collaborative meta-analysis". Hum. Reprod. J., 19: 221-231.

Shiau, C.; Wang, J. and Chen, P. (2004): "Decreased fecundity among male lead workers". Occup. Environ. Med., 61(11): 915-923.

ShuGuang, L.; JiCan, D.; LiQian, Z.; et al. (2011):"An association of elevated serum prolactin with phthalate exposure in adult men". Biomed. Environ. Sci., 24:31-39.

Snijder, C.; Te Velde, $\quad$ E.; Roeleveld, N. et al. (2012): "Occupational exposure to chemical substances and time to pregnancy: a systematic review". Hum. Reprod. Update, 18(3):284-300.

Spector, J.T.; Navas, Acien, A.; Fadrowski, J. et al. (2011): "Associations of blood lead with estimated glomerular filtration rate using MDRD, CKD $\square$ EPI and serum cystatin $\mathrm{C}$ based equations". Nephrology Dialysis Transplantation, 26 (9) : 2786 - 2792. 
Telisman, S.; Colak, B. and Pizent, A. (2007): "Reproductive toxicity of low-level lead exposure in men". Environ. Res., 105:256-266.

Telisman, S.; Cvitković, P. and Jurasović, J. (2000): "Semen quality and reproductive endocrine function in relation to biomarkers of lead, cadmium, zinc, and copper in men". Environmental Health Perspectives, 108: 45-53.

Wamoto, T.; Nozawa, S. and Yoshiike, M. (2007): "Semen quality of Asian men". Reprod. Med. Biol., 6:185-193.

Wang, L.; Li, J. and Liu, Z. (2010):"Effects of lead and/or cadmium on the oxidative damage of rat kidney cortex mitochondria". Biol. Trace Elem. Res., 137:69-78.

Weaver, V.; Lee, B. and Ahn, K. (2003):"Associations of lead biomarkers with renal function in Korean lead workers". Occup. Environ. Med., 60:551-562.

Winters, B. and Walsh, T. (2014): "The epidemiology of male infertility". Urol. Clin. North Am., 41(1):195-204.

Zenzes, M.; Puy, L. and Bielecki, R. (1999):"Detection of benzo [a] pyrene diol epoxide DNA adducts in embryos from smoking couples: Evidence for transmission by spermatozoa". Mol. Human Reprod., 5:125-131. 


\section{تأثير التعرض البيئي لكل من الرصاص والكادميوم علي الخصوبة لدي الذكور}

\section{أحمد ناهد زكي' ، و فؤاد حلمي اللدباح'، و وطارق مصطفي عمران"، مصطفي عبد المنعم محمد' و أحمد وحد الله عامر؛}

' ق قسم الطب الشرعي والسموم الإكلينيكيةـ كلية الطب - جامعة الأزهر (دمياط بنين)

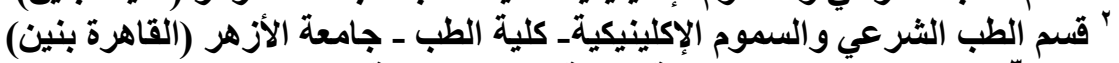

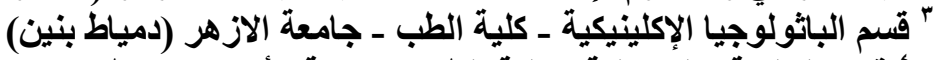

" قسم الجلاية والتناسلية ـ كلية الطب - جامعة الأز هر (دمياط بنين)

لايز ال التعرض المزمن للمعادن التقيلـة يمثل حالة طبيـة صـعبة خاصـة في الدول الناميـة. الهدف من هذه الدر اسة هو تقدير مستوى (الرصاص و الكادميوم) في الذكور غير القادرين على الإنجاب و العلاقة بين مستوى

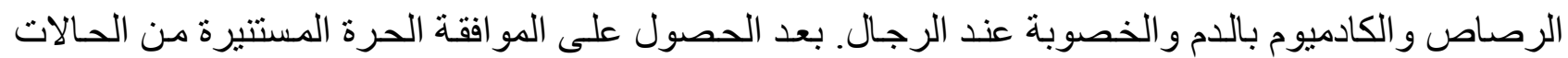
المساهمة في هذه الدر اسة، تم ضم • V من الأزواج المصابين بالعقم (بدون وجود عامل للعقم عند زوجاتهم) في عيادات العقم (قسم الأمر اض الجلدية والتناسلية والعقم، كلية طب الأزهر ، دمياط الجديدة) ومن المعروف أنهم يتعرضون للرصاص و / أو للكادميوم و المؤكد عن طريق قياس مستويات الرصساص و الكادميوم في الدم و عدد الرد

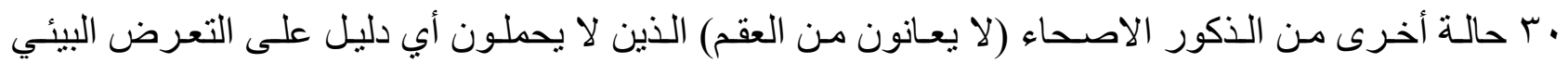

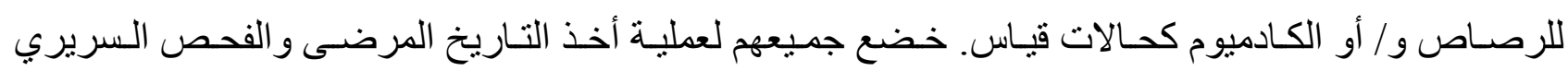
وفحص أمر اض الذكورة والتحاليل المختبريـة (تم الحصول على • ا مل مـن الدم الوريدي كعينـات لفحص

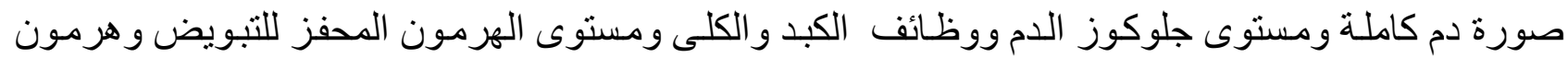

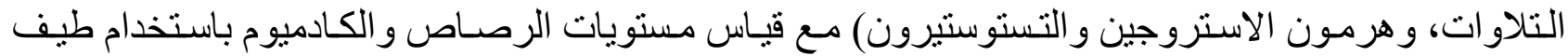

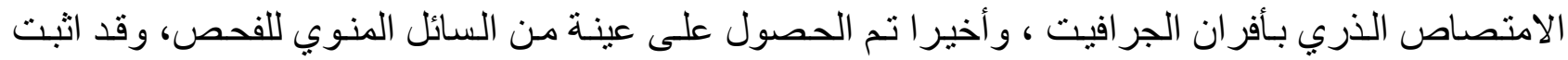

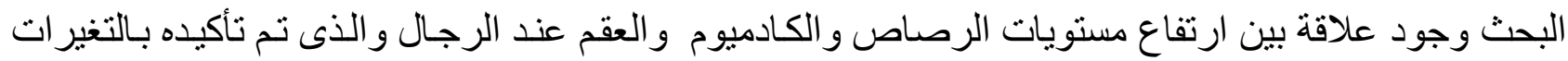
التى حدثت بمسنوى الهرمونات بالام وتحليل السائل المنوى. 